\title{
The Scope and Patterns of Organisational Politics in Nigeria
}

\author{
Ben E A Oghojafor \\ Department of Business Administration, \\ University of Lagos, Akoka, Lagos, Nigeria
}

Ik Muo (Corresponding author)

Department of Business Administration, Olabisi Onabanjo University, Ago-Iwoye, Ogun State, Nigeria. Tel: +234-803-302-6625 E-mail: muoigbo@yahoo.com

Received: February 29, 2012

Accepted: April 9, 2012 Published: May 15, 2012

doi:10.5430/ijba.v3n3p41

URL: http://dx.doi.org/10.5430/ijba.v3n3p41

\begin{abstract}
The objective of this study is to investigate the perceptions and experience of Nigerian managers as regards the nature, causes and scope of organizational politics in Nigeria. 500 questionnaires were distributed to managers in Lagos, $\mathrm{PH}$, Enugu, Ago-Iwoye and Kaduna and 200 were properly filled and returned. Descriptive statistics were used for the analyses and the study found that most of the victims of organizational politics would rather leave it to God but would have reacted differently if the labour market were more vibrant; that organizational politics is prevalent due to economic hardship and uncertainty; that its consequences include demotivation and demoralization but that it has some positive outcomes; that organizational politics is positively related to the size of the organization and that it can be minimized by enthroning an ethical culture, having concise and precise policies and decentralization.
\end{abstract}

Keywords: Organisation, Politics, Power

\section{Introduction}

Organisational politics 'involves those activities taken within organizations to acquire, develop and use power and other resources to obtain ones preferred outcomes in a situation where there is uncertainty or disagreement' (McAfee\& Champagne, 1987, 345); it is "the business of employing a constellation of forces by an individual or a group to gain advantage over others.. it is business because those involved in it look forward to bountiful gains as rewards for engaging in it"(Fajana,2002:109)it 'consists of intentional acts of influence undertaken by individuals or groups to enhance or protect their interest when conflicting courses of action are possible' (Gray and Ariss, 1995,707); with the purpose of gaining compliance from others by manipulative actions.. to shape conscious and unconscious organizational values, beliefs and practices. Resistance is reduced by the concealment of the true self - interest of the political actor (Bass, 1990,291). It is also defined as 'those activities that are not required as part of ones formal role in organization, but that influence or attempt to influence, the distribution of advantages and disadvantages within the organization (Farrell and Peterson, 1982, 405 ).

Political behaviours and considerations dominate, define and redefine the shape of organizational decisions and actions in Nigeria. The perception of political determinism is such that even when one obtains anything by merit, there is always the feeling that it must have been facilitated by somebody somewhere. In fact people start their search for anything in any organization by looking for somebody who knows somebody who knows somebody... and that is even when they are eminently qualified for whatever they are seeking.

In 2004, the Institute of Chartered Accountants of Nigeria invited one of us to deliver a paper on Organisational Politics as a part of their Mandatory Continuous Professional Education programme.(Muo, 2004). Based on personal knowledge/experience and informal discussions, the following propositions were made:

- That organizational politics is predominant in Nigeria because the macro environment thrives on political intrigues and manipulation; acute poverty, resource scarcity and unemployment, tendency to see anybody in authority as representing 'our interest' and as such bound to extend favours, the level of corruption, moral decay and little concern for integrity and a political leadership that carelessly throws its weight around and about 
- That the most popular political instruments and tactics are 'settlement', outside interference, abuse and misuse of committees, granting or denying undue/due favours, flattery and gossips, manipulation of information, use of external consultants, 'oga's boy syndrome'(cronyism) and dispensation of sexual favours by the females

- That the most influential organizational citizens are the chairman, the CEO(where his is not the chairman, core investors, female secretaries/Pas to the CEOs, Heads of Finance \& Admin, Human capital managers and sacred cows(well-connected individuals without any formal authority)

- That the most political organizations are the pure civil service, the parastatals, institutions with government interest, old generation institutions, organizations with dominant shareholders and organizations with dominant-and domineering-CEOs

The lecture was delivered in four cities across the country and after the first lecture, we decided to investigate the extent to which these 'propositions' were supported by the experience and evidence of a cross-section of Nigerian managers and that was the origin of this study. The objectives of this exploratory study in effect are to:

1. To investigate the perceptions and experience of Nigerian managers as regards the nature, causes and scope of organizational politics in Nigeria

2. To examine the extent to which these experiences and perspectives agree with propositions which I had made earlier and which are summarized above

\section{An Overview of Organisational Politics}

Organizations are supposed to be properly structured with rights, responsibilities and reporting relationships clearly spelt out, resources and privileges distributed rationally and performance-reward parity objectively maintained. In such a situation, politics in organizations would have been limited to using legitimate power to direct resources and efforts towards the achievement of 'open' corporate agenda. But rights, responsibilities and authorities are not clearly spelt out; resources and privileges are not distributed rationally and there is little performance-reward parity. Organisational citizens are thus left with no option than to jostle, to scheme and politick so as to make the best out of their work life; to improve their pay, status or authority within the organization (Muo, 2004:3; Muo, 2005a).

Whereas organizations cannot exist without some form of politics, it must be stated that the failure of managements to run organizations objectively and equitably is largely responsible for the increasing dangerous, destructive and desperate political tendencies prevalent in most organizations today.(Muo, 2005b) And surprisingly, the resultant power struggles and cut-throat actions may be as endemic to organizational life as planning, organizing, directing and controlling (Schein, 1977:64) and this pervasiveness is generally seen as harmful to the organization and its citizens(Valle\& Witt,2001:379).

Organisations as they are structured are also inherently political as they provide natural platforms for individuals to pursue individual interests and motives as in career progression (Zalzenick, 1970:48). In this apparently natural process, people try to obtain more power (by seeking promotion); maintain current power (by seeking control over other functional areas); and to eliminate other peoples' power(by striving to takeover another functional unit (Schein,1977:66). And these self-serving political behaviours may be disguised in formalized procedures and social niceties(Christiansen et al,1997:709). Organisational politics has been severally defined from the above perspective. And one of such definitions sees it as actions by individuals that are directed more towards self aggrandizement than towards the goals of the company as a whole; connote a degree of deception and dishonesty (Du Brinn;1972:177)

We are thus talking of actions taken to achieve motives that are not disclosed to other organizational citizens. These are most often aimed at maximizing the self-interest of the political operators(Ferris et all,1989:143) while being against the collective interest of the organization and some or all of its citizens(Vigoda,2000:327). Political actions generally have three characteristics: they are inconsistent with accepted organizational norms; they are designed to promote self interest and they are taken without regard for or even at the expense of organizational goals.(Valle \& Witt,2001:379) This is the popular view of organizational politics which in addition to seeing it as a parochial process, also associate it with such negative undertakings as manipulation, defamation, subversiveness and illegitimate application of power (Ferris \& Kacmar,1992:93). Most behaviours in this category are informal, ostensibly parochial, typically divisive and above all, illegitimate-sanctioned neither by informal authority, accepted ideology nor certified expertise(Mintzberg, 1983:172)

There are however other subtle manifestations of power and politics prevalent in organizations. These include getting extra budgetary approvals, obtaining above average salary increments and other perquisites of office for one's subordinates, getting fast and regular access to decision makers, obtaining advance information on policy propositions and plans, interceding on behalf of troubled staff and getting desirable placement for subordinates (Kanter, 1979,67). These moves may or may not be for selfish purposes. 
But while organizational politics are targeted at aims not sanctioned by the organization or achievement of sanctioned aims through non-sanctioned means(Meyers \& Allen, 1977:675), it is noteworthy that not all political actions are selfish; some may well be to the overall benefit of the organization. Allen et al(1979:77) support this view when they hold that organizational politics have the potentials for positive or negative consequences just as Schein (1977: 66\& 68) also argues that people may pursue personal goals that are congruent with organizational goals or those that are not congruent with the goals of the organization. The former she refers to as organizational power-related behaviours and the later as political power-related behaviours. It has also been argued that political behaviours may be offensive(self-serving) or defensive-in response to political behaviour from others(Ivancevich, 1980:272). But it must be recognized that organizational goals are not as iron-cast and sacrosanct as they are presented since they are fluid and represent outcomes of bargaining among potential coalition members that are elaborated over time in response to short-run pressures(Cybert \& March,1964:43)

It should also be re-emphasized that using formal authority to achieve organizational goals is-strictly speaking- also part of organizational politics; it involves the application of power. Units within an organization also acquire and exercise power over others. This power is acquired through access to scarce resources, ability to cope with uncertainty and thus be in a position to help others out of that uncertainty, ability to influence the work of others through positions in the workflow and when they perform essential functions that cannot be performed or completed by others (Schermerhorn et al 1994,483)

Thus, organizational politics broadly involves the following:

1. Using legitimate power to direct and control resources and efforts towards the attainment of corporate agenda. In this case everybody understands the score.

2. Using legitimate power to achieve objectives that are in the interest of the organization but may not be known by everybody involved.

3. Using all sorts of persuading and influencing tactics to get other's support for policies and programmes that are in the corporate interest but which they may be reluctant to support and you can not, or do not want to, apply coercion.

4. Using legitimate power to promote and/or protect selfish interests.

5. Scheming and manipulating people, policies, systems and processes to achieve personal interests-material or non-material.

6. Forming coalitions, creating bonds and playing the good boy so as to be readily favoured in appointments and promotions especially as one moves nearer to the top. The political operator may not be qualified for such an appointment or he may be qualified but there are other potential candidates.

7. Manipulating people, information and processes so as to wriggle out of tight corners and evade or minimize pending sanctions.

8. Scheming and manipulating people, policies, processes and systems to achieve goals that are in the interest of the organization but which formal procedures will thwart or delay. A staff may undermine corporate policy or circumvent the reporting line in his effort to quicken a new product development process.(Muo, 2006a:25; Muo, 2006)

It is important to note that people mostly relate organizational politics to the fourth, fifth and sixth scenarios(ie, negative, selfish and destructive). This category of behaviour creates what William \& Dutton (2000:4) 'term corrosive political climate' which usually leads to unfavourable individual, group and organizational consequences as individuals become less focused on organizational goals(Maddison et al, 1980:79), the flow of information becomes restricted and speed of decision making slows down(Eisenhardt \& Bourgeois, 1988:737), members withdraw psychologically and physically, employee stress increases, critical employee attitude like involvement and satisfaction decline(Cropanzano et al, 1997:180; Ferris et al 1996:233; Gandz \& Murray, 1980:237) and valuable employees defect(Pfeffer, 1992). At the extreme, such politically dominated organization may go out of control and explodes and 'nothing remains at the core-no central direction, no integrating ideology and therefore, no directed effort at efficiency, proficiency or innovation(Mintzberg, 1991:65)

It should also be noted that the organization is a political entity as it does every thing possible to befriend the government and its officials so as to derive some benefits or avoid some pains from government activities and in-activities. 


\section{Methodology}

500 questionnaires were distributed to respondents in 5 cities in Nigeria chosen for convenience but also to ensure 'federal character': Lagos, Kaduna, Port-Harcourt, Enugu \& Ago-Iwoye. All the respondents are managers and either had a university degree or a professional qualification or a combination thereof. Some of the respondents had listened to the presentation on Organisational politics while some did not. The research instrument was the questionnaire which was divided into two parts. Part 1 contained the biographic details of the respondents while part 2 contained 20 questions related various aspects of experience of organizational politics by the respondents. The questionnaires were analysed with descriptive statistics mostly, simple percentages, ratios and tables

\section{Results \& Discussions}

\section{1.: Biographic Characteristics of Respondents}

200 questionnaires were properly filled and returned indicating $40 \%$ response rate. $54 \%$ of the respondents have professional qualifications(mostly ACA); $20 \%$ are B.Sc/HND Holders while $26 \%$ have Post Graduate Degrees (mostly MBA/M.Sc). $62 \%$ had over 10 years working experience; $23 \%$ from 5 to 10 years experience and $15 \%$ less than 5 years. $77 \%$ are male, $23 \%$ are females while $90 \%$ are married. $64 \%$ of the respondents did not see themselves as organizational politicians while $36 \%$ were convinced that they were politicians. Furthermore, $48 \%$ of them would consider the political tendencies in organizations before seeking employment while the rest(52) will not bother about such issues in this era of buyers labour market

\subsection{Analyses of Responses}

An analysis of the responses revealed the following

- Prevalence of organizational politics(OP) in organisations: 77\% of the respondents reported that organizational politics was prevalent in their organizations(very common/common) while $23 \%$ reported that it was occasional/rare

- Responses/reactions to OP:79\% of the sample have been victims of OP and they reacted as follows. An overwhelming majority of those who believed to have been politically dealt with will leave it to God(60\%) rather than protest officially $(20 \%)$, pay back in kind(17\%) or even resign( $8 \%)$. A few of them would ask for reposting or plead with their tormentors. But as a follow up, $75 \%$ averred that their reaction would have been different if the employment market were more favourable than it is now. 19\% believed that their political experience was due to their tribe; $17 \%$ traced it to their religion; $14 \%$ felt it was due to their gender while $67 \%$ believed it had nothing to do with these variables

- Commonest Type of Political Tactics: respondents believed that the commonest political tactics in their organizations are nepotism/tribalism:28\%; religious politics:19\% god-fatherism(cronyism) $17 \%$ and sundry others $40 \%$

- Negative Consequences of OP: the response to this is depicted in Table 1. OP reduces staff morale and has de-motivating effect(32\%); it leads to low productivity(29\%) and power tussles(23\%) It is obviously the demoralizing effect and the power tussle that lead to low productivity.

- Minimising \& Managing OP: on strategies for managing OP, our respondents believe that the existence of clear-cut policies $(33 \%)$ and ethical culture $(28 \%)$ and decentralization of operations and power(24\%) are the key solutions to the scourge of destructive $\mathrm{OP}(\mathrm{able} 2)$

- The Most POWERFUL People in Organisations: The respondents perceive the most powerful categories of people in their organizations as The Chairman/CEO (38\%) followed by other directors(25\%) and management staff(18\%).

- Most political organizations: a overwhelming majority(68\%) believes that the civil service in Nigeria is the most political setup in Nigeria while $18 \%$ believe that it is the private firms. Others accounted for the difference $(14 \%)$

- Prevalence of OP In Nigeria: $77 \%$ of the respondents believed that organizational politics was prevalent in their organizations(very common/common) while $23 \%$ reported that it was occasional/rare. But at the national level, they all believed $(100 \%)$ that OP is common in Nigeria. On the factors responsible for this situation, our respondents believe that poverty and thus the desire to protect/promote economic interests is the major factor in OP in Nigeria( $40 \%)$ This is followed by desire for power(30\%)-this is used to achieved the above- and the desire for job security which is also linked to the first issue. Ultimately, the economic uncertainty, absence of social security and the tight labour market are responsible for the prevalence of OP. The 'others' in the response include greed, tribalism, extended family system, leadership style, level of moral decadence in the society, poor corporate governance and inappropriate reward system. Three respondents actually mentioned spiritual poverty!(see Table3) 
- Corporate Size \& OP: $70 \%$ believe that OP is more prevalent in large organizations than in smaller ones and this is because there is greater competition for resources(37\%) and the fact that there are several people with different orientations and personalities $(22 \%)$ while sundry other factors account for the rest $(31 \%)$

- Advantages From OP: $60 \%$ of the respondents believed that there are some advantages from OP while $40 \%$ are of the contrary view. They went on to list these advantages as:

○ Oiling the organizational machinery: $43 \%$

○ Increased visibility/recognition: $32 \%$

○ Others; $25 \%$

Oiling the organizational machinery aggregates the outcomes of positive organizational politics as outlined by the respondents. This includes using OP to enhance innovation and change, collaborative politics which moves the organization forward. Increased visibility/recognition is the benefit derived by the individual politicians

- Instances/experiences of OP. The respondents were also asked to recount instances of OP they had experienced or witnessed. Many of them did not give that essay-form response while some of those who did gave wrong examples. The commonest instances given by the respondents revolved around:

○ Politicization of employments, dismissals/terminations promotions, appointments, succession, and allocation of official cars

- Punitive transfers

$\circ$ Encouraging mediocrity

○ Divide \& rule

- Frustration of certain officers/offices.

- Some of these are elaborated in Appendix 1

\section{Summary of Findings \& Conclusions}

\subsection{Summary of Findings}

The findings of this study can be summarized as follows

1. OP is prevalent in Nigeria and most of the respondents(79\%) had experienced it in their places of work but only a few of them( $36 \%)$ see themselves as politicians

2. Most of the respondents who had experienced OP-induced organizational losses would rather leave the matter to God(adopt a do-nothing strategy) but $75 \%$ of them would have reacted differently if the labour market had been more vibrant

3. The prevalence is due to overall corruption and moral decay in the society, economic hardship and uncertainty, organizational resource scarcity and the tight labour market

4. The adverse consequences of Op included its de-motivating and demoralizing impact all of which lead to low productivity But respondents still believe that there are some advantages from OP

5. The respondents believe that the most common political practices involve denying due favours and granting undue ones which is traceable to cronyism and nepotism

6. OP is a function of the size (the bigger the more politicking) and sector(the civil service is the most politicized)

7. OP can be managed/minimized by enthroning an ethical culture, having concise and precise policies and decentralization.

\subsection{Conclusion}

Organizational Politics has become a common scourge in modern organizations. Even when organizations are properly structured with appropriate policies and culture, there is still the natural tendency for people to try to act beyond the book in an effort to have an edge over others in a world characterized by scarcity and uncertainty.

This exploratory study has x-rayed the field of OP in Nigeria with special emphasis to its causes, nature, patterns and experiences of the respondents. It has generated some facts as to the various dimensions of OP including its prevalence, causes, consequences, remedial measures and personal response by managers. As regards the propositions that were made in the very beginning, those that are supported by evidence include: 
- That politics is prevalent in Nigeria especially in the civil service

- That the causes are scarcity of organizational resources, economic hardship, uncertainty and tight labour market

- That the most powerful figures in the organizations are the Chairmen/CEO and top management staff

- That the most popular OP tactics and practices include granting/denying due/undue favours and all forms of cronyism

\section{References}

Bass, M. B. (1990). Bass \& Stogdill's Handbook of Leadership. New York, The Free Press

Chiristiansen, N., Villonova, P. \& Mikulay, S. (1997). Political influence compatibility: Fitting the person to the climate. $\begin{array}{llll}\text { Journal Of } & \text { Organisational } & \text { Behaviour,18, }\end{array}$ http://dx.doi.org/10.1002/(SICI)1099-1379(199711)18:6<709::AID-JOB811>3.0.CO;2-4

Cropanzano, R., Howes, J. C., Grandey A. A. \& Toth, P. (1997). The relationship of organisational politics and support to work behaviours, attitudes and stress. Journal of Organisational Behaviour; 18,159-80. http://dx.doi.org/10.1002/(SICI)1099-1379(199703)18:2<159::AID-JOB795>3.0.CO;2-D

Du Brin, A. J. (1972). The Practice Of Managerial Psychology; Elmsford, N.Y; Pergamon Press

Eisenhardt, K. M. \& Bourgeois, L. J. (1988). Politics of strategic decision making in high-velocity environments: Towards a midrange theory'. Academy of Management Journal; 3(4),737-770. http://dx.doi.org/10.2307/256337

Farrell, D. \&Peterson, J. C. (1982). Patterns of political behaviour in organizations. Academy of Management Review, July.

Ferris, G. R., Russ, G. S. \& Fandt, P. M. (1989). 'Politics in organizations.. In Giaclone \& Rossenfield(eds) Impression Management in Organisations,pp143-170, Hillsdale, N. J; Arlbaum.

Ferris, G. R., Kacmar, K. M., Galang, D. D., Zhou, M. C. \& Howard, J. L. (1996). 'Perceptions of organisational politics: Prediction, stress-related implications and outcomes’; Human Relations, 49(2), 233-266. http://dx.doi.org/10.1177/001872679604900206

Gandz, J. \& Murray, V. (1980). The experience of workplace Politics. Academy of Management Journal, 23(2)237-251. http://dx.doi.org/10.2307/255429

Madison, D. L., Allen, R. W., Porter, L. W., Renwick, P. A. \& Meyes, B. T. (1980). 'Organisational politics: An exploration of managers perceptions. Human Relations, 32(2) 9979-10000

McAfee, R. B. \& Champagne, P.G. (1987). Organisational behaviour; Managers view. St. Paul, M N; West Publishing Company

Mettam, G. R. \& Adams, L. B. (1994). How to prepare an electronic version of your article. In B. S. Jones, \& R. Z. Smith (Eds.). Introduction to the electronic age (pp. 281-304). New York: E-Publishing Inc.

Mintzberg, H. (1983). Power in and around organisations; Englewood Cliffs, Prentice Hall

Mintzberg, H. (1991). The effective organisations: Forces and forms. Sloan Management Review, 32(2),54-67)

Muo, I. (2004). Coping with the political environment of the workplace. Paper delivered at the 2004 ICAN MCPE programme, Airport Hotel Lagos, March $10^{\text {th }}$

Muo, I. (2005a). N25bn capital base and the tempo of organisational politics in the Nigerian banking Industry. Journal Of Banking, 1, June

Muo, I. (2005b). Navigating the murky waters of organisational politics through the ' $2 M$ FRAMEWORK'. Nigerian Management Review, 16,(1) January-June,1369-1380

Muo, I. (2006a). 'Managing the political dynamics of the workplace. Lagos Organisational Review,2 (4). May-July, 46-59

Muo, I. (2006b). Perception of organisational politics and work attitude amongst the academic staff of Nigerian Universities. Unpublished M. Sc. Thesis, University of Lagos, November, 2006

Pfeffer, J. (1992). Managing with power: Politics and power in organisations Boston, Harvard Business School Press

Schein, V. E. (1977). Individual power and political behaviours in organisations: An inadequately explored reality. Academy of Management Review, January.2(1) 64-72 
Strunk, W. Jr. \& White, E. B. (1979). The elements of style. (3rd ed.). New York: Macmillan, (Chapter 4).

Valle, M. \& Witt, L A. (2001). The moderating effect of teamwork perceptions on organisational politics-job satisfaction relationship., Journal of Social Psychology, 13,(3),379-388. http://dx.doi.org/10.1080/00224540109600559

Vigoda, E. (2000). 'Organisational politics, job attitudes and work outcomes: Exploration and implications for the public sector. Journal of Vocational Behaviour, 57,326-347. http://dx.doi.org/10.1006/jvbe.1999.1742

Williams, M. \& Dutton, J. E. (2000). Corrosive political climates: The heavy toll of negative political behaviour in organizations. In O'neil et al (eds) Pressing Problems in Modern Organisations; New York, AMACON; pp3-30

Zalzenick, A. (1970). "Power and politics in organisational life. Harvard Business Review, 48( 3), 47-60

Table 1. Consequences of OP

\begin{tabular}{|l|l|l|}
\hline S/N & Consequence & $\%$ \\
\hline 1 & Demoralize/de-motivate & $32 \%$ \\
\hline 2 & Low productivity & $29 \%$ \\
\hline 3 & Power tussle & $23 \%$ \\
\hline 4 & Staff Turnover & $10 \%$ \\
\hline 5 & Others & $6 \%$ \\
\hline & & \\
\hline
\end{tabular}

As can be seen from the above table, respondents firmly believe that OP reduces staff morale and has de-motivating effect [32\%]; it also leads to low productivity [29\%] and power tussles [23\%] and higher staff turnover. These factors are actually interrelated. The demoralization, de-motivation and power tussle will obviously lead to low productivity and poisoned organizational climate which leads to higher staff turnover

Table 2. Strategies for Containing OP

\begin{tabular}{|l|l|l|}
\hline $\mathrm{S} / \mathrm{N}$ & Solution & $\%$ \\
\hline 1 & Precise policies & $33 \%$ \\
\hline 2 & Ethical standards & $28 \%$ \\
\hline 3 & Decentralisation & 24 \\
\hline 4 & Others & $15 \%$ \\
\hline
\end{tabular}

Table 2 indicates the respondents views on how to contain Op in Nigerian organizations: clear-cut policies [33\%], ethical culture [28\%] and the decentralization of operations and power [24\%]

Table 3. Factors Responsible For The Prevalence of OP in Nigeria

\begin{tabular}{|l|l|l|}
\hline $\mathrm{S} / \mathrm{N}$ & Factor & $\%$ \\
\hline 1 & Economic/Poverty & $40 \%$ \\
\hline 2 & Desire for Power & $30 \%$ \\
\hline 3 & Job security & $23 \%$ \\
\hline 4 & Others & $7 \%$ \\
\hline
\end{tabular}

Table 3 indicates that our respondents belif that poverty and thus the desire to protect/promote economic interests is the major factor in OP in Nigeria[40\%] This is followed by desire for power[30\%]-this is used to achieved the above- and the desire for job security which is also linked to the first issue. 
Appendix One: Some Respondents Accounts of Organisational Politics

Below are some of the instances of OP experienced or witnessed by our respondents. These are reproduced as stated by them except for minor grammatical corrections. The headlines were however provided by the authors. Brief biographical details of respondents are enclosed where available at the end of each example-sex, qualifications, years of experience and organization).

\section{Case 1. Village Rivalry Overflows To The Office}

This happened to a close friend of mine. I joined the company newly with this friend and as God will have it, he was immediately posted on a job with a senior in port Harcourt. This my friend hailed from a rivalry village to that of the senior both of whom are from Benue state. Due to this village rivalry, the senior had a serious dislikeness for this my friend and found fault with whatever he did. This annoyed my friend who was also politically inclined. The matter eventually came to the attention of some other managers who made efforts to resolve the issue but these efforts proved abortive. This indecent discrimination went on until my friend could not contain it any more and he had to resign. (Respondent: A Consultant, B.Sc, 5 years experience)

\section{Case 2. Tenure Extension by Sacking The Likely Successor}

Somebody who was supposed to succeed the MD suddenly lost the job and this was obviously engineered by the MD. The reason was that the MD was not yet ready to go after being in the saddle for 10 years. Sacking the man thus gave him more time as the MD and also the opportunity to groom his favourite as a successor(Respondent: Male, B.Sc, 6-10 years work experience in an ICT firm).

\section{Case 3. Training For the Boys \& Political Re-Alignment}

Training in my organization is based on the policy of every staff being trained at least once a year and for management staff, this training should be overseas. When it was my turn to attend local courses, the management would say that I should not go because I was doing verry well in my job. This happened for three years until the Head of Human Resources advised me to go and appeal to the CEO. I reluctantly did as advised and pronto, I was sent on course as an when due! The same scenario played itself out in the overseas courses as the CEO saw it as a favour for his 'people'. For 4 years running, I would be advised to prepare for a course and at the last minute, my name would be dropped and substituted with another. At times the excuse would be that the course was not right for me. Eventually and against my style, I had to align with the dominant and influential group in the organization. Since then, I had attended overseas courses two times a year for two consecutive years. I now do the groups biddings which are largely not in the interest of the organization Although I am not fulfilled as a manager, the fact that I belong to the right group ensures that I get everything due to me and even more!(Male, M.Sc, 10 years work experience)

\section{Case 4. Castration of the Office \& the Officer}

I was appointed an Assistant Internal Auditor for a company belonging to the government. But my attempt to assume duties was frustrated by the MD. He did not have anything against me but he just did not want the internal audit unit-which I was to head-to be functional!(Male, ACA)

Case 5. Post-Election Vengeance \& Crises in an Educational Institution

During the contest for the for the headship of our institution, my boss, the Acting Bursar was not in the camp of the candidate who eventually won. When he won, he dealt with the Acting Bursar by ensuring that he was not confirmed as the substantive bursar. Those who were friendly with the acting bursar were also dealt with. I was denied the opportunity of attending a conference which would have boosted my knowledge and earned me thousands of Naira but a junior officer with HND was nominated. Eventually, opposition against him swelled because of his vengeance politics and the unions rose against him and he was sent parking( Male. B.Sc/MBA, 10 years experience)

\section{Case 6. Discriminatory Wedding Gifts}

In my company, a certain amount of money is always given to staff who got married as wedding gifts. When it was my turn, I was not given a penny and when a confronted the CEO he said it was not mandatory for every staff to receive that gift. Yet it had always been given to everyone who wedded.

\section{Case 7. Swimming Against the Tide}

I was recently posted to head the Finance \& accounts department of my organization. This meant that I should boss the incumbent. Sadly \& unknown to me, the incumbent was a younger brother to my director. the Executive secretary of the organization also hailed from my directors state. A political power game ensued and with the consequential manipulations. Three months later, I was denied the opportunity to head to accounts department and I was returned to 
the status quo. Up to this moment, that event strained the relationship between me and my director who felt that I lobbied to occupy that position(Head,F/A). I have since suffered terrible postings as a result of the impression of my director because he is a key factor in the deployment of officers in the organization( Male, HND,ACCA,MBA; $>10$ years experience)

\section{Case 8. Different Strokes for Different Folks}

When I qualified as a chattered accountant, I remained in the same post for more than a year before I was upgraded but when another colleague of mine from another tribe qualified, he was qualified after a few months(Male, $\mathrm{HND} / \mathrm{ACCA},>10$ years)

\section{Case 9. Caught in the Cross-Fire}

The chairman and the MD were not the best of friends and the MD felt that I was rather too close to the chairman. That was why and how I was suspended without query by the MD. I had gone on leave and he asked internal auditors to inspect our records. The auditors reported that some funds were placed on the company's call accounts and the MD said he was unaware of that placement. Based on that, he suspended me without even a query but the main reason is my relationship with the chairman(Male, ACA,HND,MBA;>10years)

Case 10. Professional Vs Non-Professional

Before I was employed as a professional accountant, there was a non-professional who was performing accounting duties. She felt threatened! Being the wife to the Vice Chancellor, she used her 'good offices' to ensure that I was not given the position for which I applied even though I did all the relevant work(ACA,MBA,>10years, University)

Case 11. If You Don't Belong, You are Finished

The senior staff in my organization can do anything to attain higher positions. They write petitions against their superiors to higher authorities to engineer their ouster. They demote, transfer or submit names of staff for compulsory retirement so that they or their favoured candidates can move forward. If the junior staff do not worship them, they are readily transferred or subjected to other forms of victimization. If you don't belong to ther clan, state or linguistic group, you are in trouble. They play and laugh with you so that you don't know their true intentions but once you are not around, they plot against you. When opportunities arise, only those that belong to their groups are favoured(Female, ACA, HND,MBA; $>10$ years)

\section{Case 12. The First Shall Be The Last}

A professionally qualified and technically competent accountant was made subordinate to a less qualified, less competent staff because the CEO wanted to use the less qualified accountant, whom he found more pliable, to achieve selfish objectives(Male, ACA,5-10 years)

\section{Case 13. Your 'Sins' Will Find You Out!}

Three of us were employed in our organization based on competence and qualification through a competitive process. Because of that, the candidates sponsored by the boss did not scale through. Consequently, and in anger, the boss placed us in a lower entry position that was merited by our qualifications. The battle is still on(Male, HND,ACA,MBA; >10years 